Portland State University

PDXScholar

\title{
Affordable Housing for Public Benefit: a Comparison of Newly Constructed and Rehabilitated Developments in the North and Northeast Neighborhoods of Portland, Oregon
}

Sara Matijascic

Portland State University

Follow this and additional works at: https://pdxscholar.library.pdx.edu/honorstheses Let us know how access to this document benefits you.

\section{Recommended Citation}

Matijascic, Sara, "Affordable Housing for Public Benefit: a Comparison of Newly Constructed and Rehabilitated Developments in the North and Northeast Neighborhoods of Portland, Oregon" (2014). University Honors Theses. Paper 102.

https://doi.org/10.15760/honors.76

This Thesis is brought to you for free and open access. It has been accepted for inclusion in University Honors Theses by an authorized administrator of PDXScholar. Please contact us if we can make this document more accessible: pdxscholar@pdx.edu. 


\section{Affordable Housing for Public Benefit: A Comparison of Newly Constructed and Rehabilitated Developments In the North and Northeast Neighborhoods of Portland, Oregon \\ by \\ Sara Matijascic}

An undergraduate honors thesis in partial fulfillment of the requirements for the

Degree of Bachelor of Arts

in

University Honors

and

Community Development

Thesis Adviser

Dr. Matthew Gebhardt

Portland State University

2014 
Matijascic

\section{Table of Contents}

$\begin{array}{ll}\text { Abstract } & 3\end{array}$

$\begin{array}{ll}\text { Introduction } & 3\end{array}$

Figure 1.1 Housing Cost-Burden in Portland, OR; 2008-2012 4

Figure 1.2; African-American Population Change, 2000-2010 6

Figure 1.3; Percent Change in Median Home Value 2000-2010 7

$\begin{array}{ll}\text { Terms } & 10\end{array}$

$\begin{array}{ll}\text { Literature Review } & 13\end{array}$

$\begin{array}{ll}\text { Methodology } & 17\end{array}$

$\begin{array}{ll}\text { Survey } & 20\end{array}$

Rationale and Results of the Survey 22

$\begin{array}{lr}\text { Case Studies } & 29\end{array}$

$\begin{array}{ll}\text { Results } & 30\end{array}$

$\begin{array}{ll}\text { Conclusion } & 31\end{array}$

$\begin{array}{ll}\text { Works Cited } & 33\end{array}$

Appendix A: Survey

A1) Public Benefits Survey 36

A2) Survey Responses $\quad 40$

A3) Public Benefit Point System 45

Appendix B: Case Studies

B1) Case Study Profiles 46

B2) Public Benefit Assessment 50

Appendix C: Cost Data $\quad 52$ 
Matijascic

\section{Abstract:}

Rising property values and low vacancy rates have led to a high demand for affordable housing in Portland, Oregon. In order to fulfill this need, a strategy that considers development cost and potential benefits of affordable housing to the public must be put into place. In this report, I compare development cost and public benefit of two housing creation methods - new construction and rehabilitation - to determine ways to increase economic feasibility, as well as positive externalities of the development process. This inquiry is tested using a public benefit survey that was distributed to housing professionals working in Portland, Oregon. The results of the survey were then applied to four case studies developed in North and Northeast Portland, between 2005 and 2013, by a local community development corporation, Portland Community Reinvestment Initiatives, Inc. The results of this report contribute to the larger goal of creating a comprehensive affordable housing plan for Portland, Oregon, which emphasizes that anyone and everyone in Portland stands to gain from the provision of housing for all.

\section{Introduction:}

Portland, Oregon is experiencing a shortage of affordable housing in the midst of rising property values and a narrow rental market. The vacancy rate in 2013 was "at or under 3 percent... among the lowest in the nation" (Cordell, 2013). The 2012 American Community Survey 5-year estimate, paints an even direr picture: $40.6 \%$ of Portland households spend $30 \%$ or more of their monthly income on housing alone, qualifying these residents as "Housing Cost Burdened" (see Figure 1.1). This means that after 
Matijascic

accounting for housing, these households must compromise or forgo other necessities like transportation, food, education and healthcare.

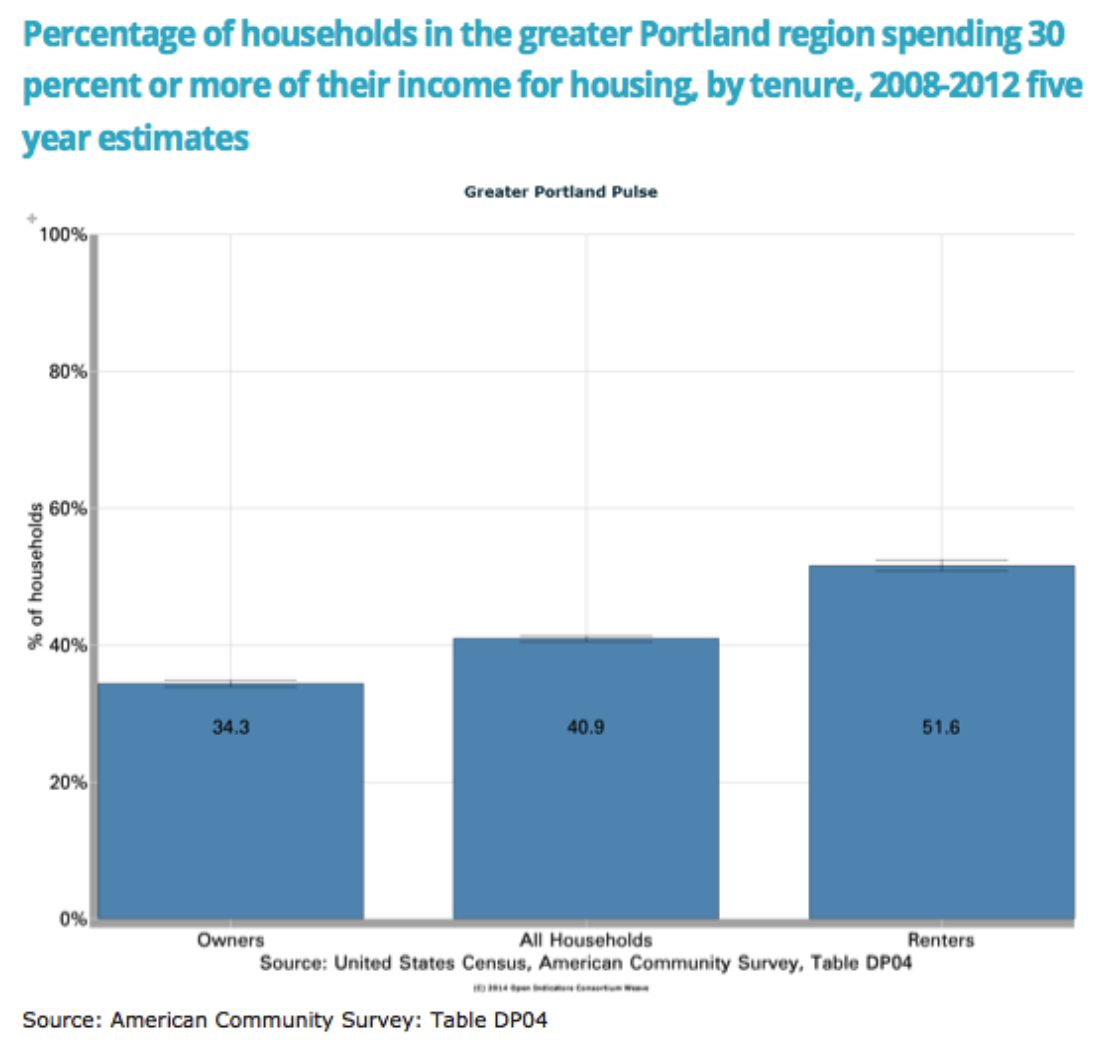

Figure 1.1 Housing Cost-Burden in Portland, OR; 2008-2012

This statistic tells us that over one third of Portland households need affordable housing. Furthermore, in Portland, as on the national level, those experiencing housing cost burden are disproportionately renters who are people of color and low wage earners (Harvard University, 2013). To meet the demand for affordable housing, developers have two options: construct new units or rehabilitate existing units. This report seeks primarily to understand the public benefits associated with each strategy, and also their 
Matijascic

economic feasibility as implemented in North and Northeast Portland, Oregon between 2005 and 2013.

The study area of North and Northeast Portland was selected due to the acute need for affordable housing in order to mitigate the displacement of the African-American population caused, at least in part, by the increase of rents and prices (see Figure 1.3). Over the past decade, African-American residents located in this area have been forced to relocate away from the city center (see Figure 1.2). In the past decade, North and Northeast Portland neighborhoods gained a reputation as a trendy place to live, attracting residents in pursuit of housing that was less expensive than other areas of Portland and other cities in the US. In-migration to Portland has raised the value of homes and led to one of the nations lowest vacancy rates (Cordell, 2013). 
Matijascic

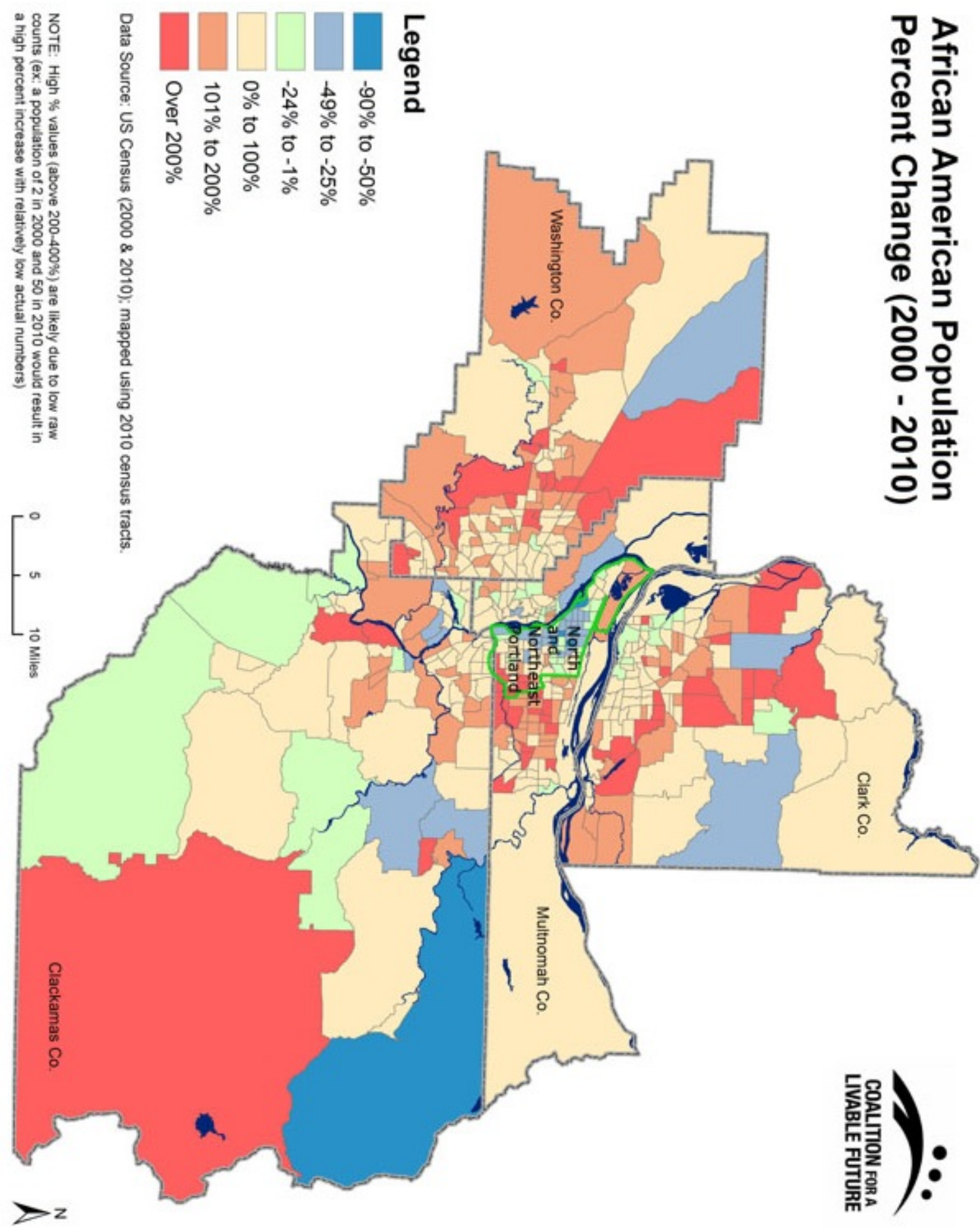

Figure 1.2; African-American Population Change by Census Tract, 2000-2010 
Matijascic

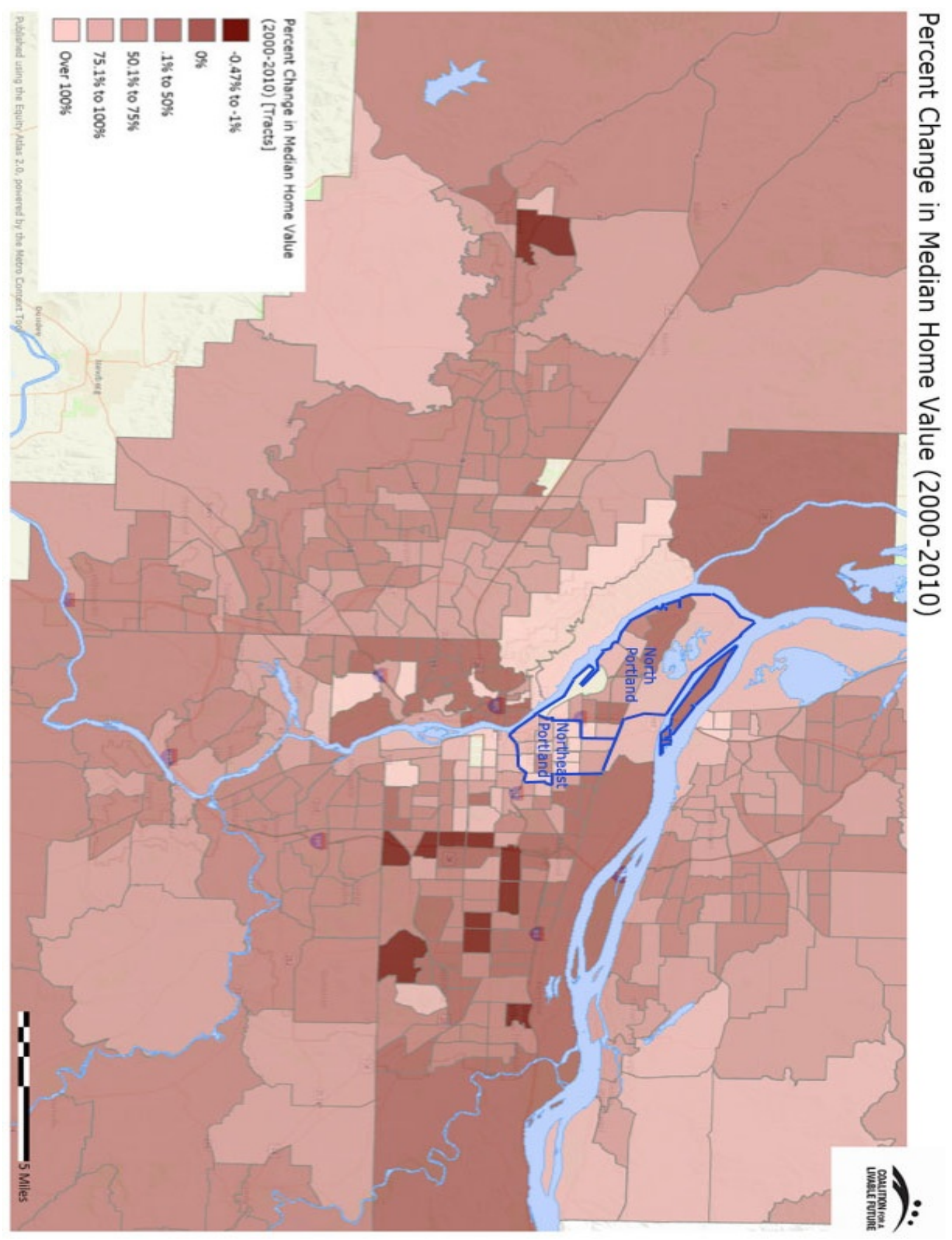

Figure 1.3; Percent Change in Home Value 2000-2010, by Census Tract 
Matijascic

Considering the movement of African American households out of North and Northeast Portland alongside the change in median home values in this area over the past ten years, (compare Figures 1.2 and 1.3) it is clear that rising housing cost leads to displacement. Therefore, creating more affordable housing in that area is a strategy to slow this trend. Due to the historical context of racial discrimination in Portland housing, care must be taken in fulfilling that need (Gibson, 2007). This report argues that developers and policy makers should take advantage of the opportunity not only to increase the supply of affordable housing in Portland, Oregon, but also to promote public benefit through design and the development process. At the same time, this study recognizes the importance of minimizing development cost as a strategy to increase the likelihood of affordable housing development.

In order to determine a comprehensive strategy to create affordable housing, I compare the monetary costs and public benefits of two new-construction and two rehabilitated single-family homes in North and Northeast Portland. The goal of this comparison is to determine not only whether new construction or rehabilitation has the lowest monetary cost for the developer, but also which strategy provides the greatest public benefits. The developer of the cases used in this study is Portland Community Reinvestment Initiatives, Inc. (PCRI), a Portland 501 (c)(3) non-profit community development corporation (CDC). The context of this report is further specified by time, due to changes in federal and state policies regarding funding for affordable housing, the ever-fluctuating housing market, and greater demand for affordable housing due to the foreclosure crisis of the mid 2000's - early 2010's. 
Matijascic

Founded in 1992, PCRI works "to preserve, expand and manage affordable housing in the City of Portland and provide access to and advocacy for services to (our) residents." ("Mission", 2014) This study is pursued in order to assess the viability of PCRI's affordable housing strategy, which consists of temporary rental housing alongside homeownership and financial counseling in order to encourage and prepare residents for the transition out of PCRI-provided rental housing and into their own home. Their portfolio consists of over 700 units, most of which are single-family, scattered-site homes located in north and northeast Portland. Many of these units are historic and were rehabilitated or renovated by PCRI and maintained as rental housing for participants in their homeownership counseling, education, and support program. However, there are a few new-construction duplex units for homeownership in the portfolio as well. The goal of this report is to offer insight that can be used by policy makers, developers, and other organizations involved in affordable housing in North and Northeast Portland to better serve their clients and the residents of Portland, Oregon

I use both a quantitative and qualitative approach to the assessment of these affordable housing creation strategies. Public benefits are calculated according to a point system that assigns numerical value to defined social factors, based on the results of a survey distributed to people working in the housing field in Portland, Oregon. By measuring perceived public benefits, which are defined as benefits that can be enjoyed by anyone and everyone (Samuelson, 1954) - rather than benefits to the affordable housing residents or developers alone, the case for comprehensively-planned housing, and more of it, is made on a broader scale. Since the creation of affordable housing affects the property market of the city, the character of a neighborhood, and the quality of life of 
Matijascic

residents and neighbors, an approach to affordable housing that takes the voices of the public into account is utilized, and thus encouraged, through the survey that provides the foundation of my methodology.

There is no single solution that works regardless of context. But there are certain factors that influence the viability of one strategy over the other. One of these factors is cost. Theoretically, low development costs increase the likelihood of affordable housing creation and encourage the developer to create more units. But public benefit, as interpreted by residents, developers and the community, is another factor that must be taken into account. The public's perception of affordable housing, which is often negative, is a barrier to affordable housing development in the centrally located neighborhoods that need it the most. This report seeks to prove that affordable housing can, in fact, benefit all residents of the city. When all of these voices - affordable housing residents, developers, and community members - are taken into account, a comprehensive strategy that redefines affordable housing more positively - as a benefit to the public - can be utilized. By understanding the associated costs and benefits of new construction and rehabilitation, affordable housing developers in the public, private, and non-profit sectors can adapt to more efficiently and effectively serve residents and the community.

\section{$\underline{\text { Terms }}$}

I frequently use several ambiguous words. One such term is "affordable." A home is considered affordable if the household spends no more than $30 \%$ of their gross 
Matijascic

income to rent or own their home. Therefore, affordability varies on a case-by-case basis depending on a household's location, income and how many people are in their

household. To serve this variety of need, a city's portfolio of affordable housing must include units that are affordable at various income levels. In this report, affordability of a development is specified by "percent median family income" (\%MFI). This number is determined by dividing a household's income by the average household income in a given area. The U.S. Department of Housing and Urban Development (HUD) specifies affordable housing developments targeted at one of three \%MFI groups: 0-30\% MFI is extremely low income, $30-60 \%$ is very low income, and $60-100 \%$ is low income. To explain, if an affordable unit is intended to serve extremely low-income families, it will be designated as affordable for people who earn $30 \%$ MFI or below - that is, $30 \%$ of the median family income, where the MFI is calculated for a specific area; in the case of this study, Portland, OR

Another important term is "rehabilitation." The basic explanation of this term is the process of preparing an existing unit of housing for occupation by a resident. The degree to which a unit must be "prepared" varies greatly. At PCRI, some units may require only cosmetic rehabilitation - new paint or carpet. Others necessitate structural rehabilitation - repairing the foundation or replacing the roof. This variation complicates comparison of rehabilitation case studies because the costs can be wildly different depending on the rehabilitation process. In this report, case studies were selected based on similarities in rehabilitation process in an attempt to limit this variable, though it is impossible to limit variation completely. 
Matijascic

In order to understand public benefits of affordable housing, it is helpful to know the meaning of "use horizon." This term denotes how long an affordable unit, as mandated by policies and funding sources, must remain affordable before it can be sold or rented at market-rate. For example, most federal funding for affordable housing attaches a use horizon of 10 to 20 years. Most funds from the City of Portland require a 60-year use horizon. Use horizon is a mechanism to ensure future affordability and regulate funding, especially in the case of developers who take advantage of affordable housing funds in the development process but intend to sell units at market rate. The Portland Housing Bureau (PHB), the City department that oversees housing in Portland, distributes most federal funds, which originate at the U.S. Department for Housing and Urban Development (HUD). They are also in charge of local funds such as those generated through Tax Increment Financing (TIF), a common development tool in Portland (Stapleton, 2009). The Portland Housing Bureau designates the use horizon for all funding that they provide, even if it originates elsewhere like HUD, at 60 years. So units developed with PHB-distributed funds must remain affordable for at least 60 years. That said, occasionally funds are available to developers from other sources - trusts or directly from HUD, for example. These funders establish their own use horizons. In the case of funds administered directly through HUD (without first going through the PHB), the use horizon for projects that receive these funds is only 10-20 years. In assessing public benefits, survey respondents agree that neighborhood stability is important (Appendix A1). One way to promote stability is to encourage longer tenure of homes by residents. In the context of a gentrified/gentrifying neighborhood such as Northeast and North Portland, establishing a longer use horizon is an effective way to do this. 
Matijascic

Benefit-cost analysis is a technique used to assess present and future theoretical outcomes of a decision. Using statistics, it predicts how factors such as time and space will affect a project or policy. This method is unique in that it assigns monetary value to non-monetary factors in order to determine "true cost." As Edward Gramlich, an economist active in U.S. housing policy in the $20^{\text {th }}$ century, points out, "The role of benefit-cost analysis is to aid in decisions, but not actually to make them" (Gramlich, 1990 p. 6). While benefit-cost analysis informs the theoretical framework for this study, the methodology of this report is more accurately referred to as a "benefit-cost comparison." The element of the benefit-cost analysis method that I find most worthwhile is the comparison of non-monetary externalities with cost. For this report, the public benefits are the potential positive externalities that result from affordable housing. Unlike a true benefit-cost analysis, I look at costs and benefits at one point in time (2014), rather than projecting for the future.

\section{Literature Review:}

The field of affordable housing studies has changed throughout history depending on policies and social trends that affect the housing market. Spurred by Urban Renewal policies in US cities in the mid- $20^{\text {th }}$ century, increasing scholarship was devoted to determining the best way to house "the urban poor" (Schaaf, 1969). More recently, in the early 80's and again in the 2000's, the Urban Renewal context has shifted to recession/foreclosure discourse. Another transition that occurs over this time is the reversal of movement from the city to suburbs dating from WWII, to movement from suburbs into the city beginning in the 70's (Smith, 1996). The increasing desirability of 
Matijascic

urban living led to reinvestment from all sectors in neighborhoods previously deemed "blighted," that were now being populated by upper-class households (Beauregard, 1986). The resulting displacement of longtime residents who are unable to meet the demands of rising property values are forced out of their neighborhood, which often serves as the epicenter of a community defined by racial or socioeconomic similarity. Therefore, displacement due to gentrification must be addressed in the development of affordable housing in North and Northeast Portland, as with any other urban American neighborhood.

Literature that assesses rehabilitation, new construction, or both methods of affordable housing creation, tends to fall into one of two categories. The first, exemplified by Schaaf (1969) and Grigsby (1983) concentrates on monetary costs and benefits of affordable housing via rehabilitation versus construction. Though greater complexity regarding aesthetics, social benefits, etc., may be addressed, the topic is generally reduced to one of money in order to determine which method benefits the developer. In this money-centric camp, rehabilitation tended to be the favored mode of affordable housing creation until the more recent consideration of long term energy efficiency. The second approach to the rehabilitation-versus-new-construction question is concerned with the social and political outcomes of affordable housing creation. Here, housing is often tied to social capital theory (Saegert, 2006), focusing on the benefit to the resident. This approach is supported by community developers and the non-profit sector, who believe that affordable housing can serve as a strategy for addressing historical injustices, such as redlining and predatory lending. This report combines the 
Matijascic

money-centric approach as a response to scarce funding for affordable housing, and also the second, human-centered approach for its holistic perspective of housing.

Eventually, literature that combined both the economic and the social approach surfaced in the early 80's. Scholars such as Listokin (1983) and Pomeranz (1983) consider monetary costs alongside long-term efficacy (will affordable housing created now remain affordable in the future?) and investment in the residents (does the appearance and type of housing increase the capacity of residents and the community?). This approach is interdisciplinary, combining many fields including economics, history, sociology, and architecture.

Among these schools of thought, case studies are a common tool used to assess affordable housing creation in various US cities. However, most existing case studies are located in older, postindustrial eastern cities. Due to innumerable variables, the method of affordable housing creation that is deemed successful in one city may not be successful in another. Therefore, this report makes an important contribution to the existing affordable housing literature by focusing on a West Coast, mid-sized city. As Portland grows, both in population and in reputation as one of the most "livable" cities in the world (Ozawa 2004), a careful assessment of its affordable housing is warranted.

The voices and opinions explained above have their own ways of contributing to a couple affordable housing themes. Listokin and Pomeranz, for example, emphasize the importance of a far-sighted, comprehensive approach to affordable housing. Following the move towards an interdisciplinary perspective on affordable housing, scholars have weighed initial costs and benefits with projected future costs and benefits, both on a monetary and a social basis, using Cost Benefit Analysis (Listokin, 1983; Pomeranz, 
Matijascic

1983). For example, the initial cost of installing energy efficient appliances is greater than installing conventional appliances. The initial benefit is saving energy. Over time, this investment, though adding to your development costs at first, will theoretically pay for itself. Therefore, with the added factor of time, what appears to be a poor decision regard to cost, actually becomes a wise one, along with the added social benefit of deferring utility cost savings to the family that lives in it, thereby decreasing their household expenses.

One debate is over who - the public, private, third sector, or a combination should be responsible for developing housing and what type - multi-family, singlefamily, duplex - of housing should be created to meet affordable housing need (White, et al. 1997). The answer to these questions depends on which school of thought, as listed above, one identifies with. For example, if one believes that the least expensive solution is best (Schaaf, 1969), they may argue that multifamily units created by the private sector is the most effective affordable housing solution. This argument relies on bypassing the regulations and increased soft costs associated with the public sector (White, et al. 1997). On the other hand, if you are primarily concerned with increasing the capacity of residents and neighbors and contributing to a safe, pleasant atmosphere, you would likely argue that affordable housing should consist of single-family units with space for a yard and that remain aesthetically cohesive with the neighborhood.

This report applies the themes and questions explained above in an attempt to combine the economic and social approaches to affordable housing creation. Additionally, my work contributes to the relatively small number of West Coast, midsize-city case studies present in affordable housing literature. 
Matijascic

\section{Methodology:}

In order to determine which affordable housing strategy to use in North and Northeast Portland, I combine a cost analysis to evaluate economic feasibility with a survey and case studies to assess ways to maximize public benefit. The "Cost" part of the analysis refers to the total development cost. The cost is converted into 2014 dollars using the Consumer Price Index to account for inflation. This report looks at three categories of cost that apply to any development. First, a developer needs a site for the project. The price paid for the land is "acquisition cost." This cost varies depending on location, size, whether there are structures already existing on the land - which can add or subtract value to the land, depending on the condition of the structure - and whether the land needs some sort of preparation - if it is a Brownfield, for example. Of the four case studies used in this report, only one had an acquisition cost. That means that the developer, PCRI, received the land for the other three at no cost.

Next, a developer looks at the cost of the physical ingredients of the project: the materials and labor. This category is referred to as "hard costs." As the cost data table for the case studies shows, and as I had predicted, new construction tends to have much higher hard costs than the rehabilitated homes. This can typically be expected, since basic features of the structure are usually already present in a rehabilitated project, thereby avoiding some materials and labor costs.

Alongside hard costs are the soft costs of a project. Soft costs are indirect development costs, like permits, market studies, closing costs, the developers' fee and other non-material or non-labor costs. The rehabilitated case studies have significantly lower soft costs than the new construction cases. I expect this is because a preexisting 
Matijascic

structure is used in rehabilitation; so previous developers already completed some steps in the new construction development process. Each of these three categories of cost are dependent on place, time, and the developer, which impact factors such as policies, funds, historical preservation codes, environmental practices and more.

For the four case studies used in this report, the developer, location, and time are controlled variables. Therefore, I expect that the development process and costs will be similar across the board for new construction projects, just as the process and expenses for rehabilitated projects will remain similar within that category.

When talking about costs, it is important to note that the way development costs are measured can alter perception of the results. For example, in a previous Portland housing cost study that sought to determine whether single-family, multi-family, or duplex housing was more cost effective, it was discovered that when calculating costs using cost-per-square-foot, single-family homes appear less expensive. On the other hand, when measuring cost per unit, multifamily housing appears less expensive (White, et al. 1997). Here, cost per square foot will be used, since this tends to be most common measurement in the cost data I used. Still, it is important to be aware of the importance of the metric used to determine monetary costs.

The cost data used for this report is purely quantitative data. But to calculate "Public Benefit" I began with qualitative data. Public benefit is defined in economic terms as a good "which all enjoy in common in the sense that each individual's consumption of such a good leads to no subtractions from any other individual's consumption of that good" (Samuelson, 1954). No one can be excluded from consumption of a public benefit. Examples of public benefits as they pertain to 
Matijascic

affordable housing creation include local economic stimulation, increase in housing options, or aesthetic improvements. Despite Samuelson's definition, public benefits are subjective in terms of their perceived value. In order to standardize the value of public benefits and convert this variable into something quantifiable, I designed a survey. The survey consisted of a list of 18 potential public benefits (Appendix A1). The survey was then distributed to people involved in affordable housing development in Portland, Oregon - from housing developers to asset managers to professors - in the public, private, and non-profit sectors. Sixteen of the benefits are applied to a Likert scale; the other two are a fill in the blank with two options. The survey is designed to fulfill two purposes. First, to give a weighted value to each benefit that is used to assess the case studies. This shows whether new construction or rehabilitation, as affordable housing development strategies, has the potential to provide greater public benefit. The second goal is to see how the perception of value of each public benefit varies among developers from each sector.

The framework for analysis is applied to four case studies. The case studies consists of two newly constructed properties for homeownership, and two single-family rehab units for rental. Each was developed by PCRI in Northeast Portland and completed between 2005-2012. The costs for each development come from records kept by PCRI and are adjusted to 2014 dollars. The public benefits of each case are determined based on an assessment form that is created based on survey responses (see Appendix B2). Through site visits, I determined whether the case study fulfilled the public benefits that survey respondents considered to be important. 
Matijascic

\section{$\underline{\text { Survey }}$}

The aforementioned literature emphasizes that public benefits that can be realized or maximized via well-informed, well-planned affordable housing. However, the suggestions for how to do so tend to be theoretically hypothesized without practical application. Therefore, in order to better understand strategies to maximize public benefits in practice, I created a survey based on specific public benefits that appeared in the literature and through my own knowledge and observation. The survey was distributed to professionals in the housing field in Portland, Oregon who work in the public, private, and non-profit sectors. Respondents work in a variety of different roles, from University Professors to Housing Development Directors and Asset Managers. The variation of respondents in terms of sector and role provides a comprehensive basis on which to assess and inform affordable housing development strategies.

The survey was designed to approach public benefits from five different angles: design, access, economic development, policy, and community development. This comprehensive approach, as opposed to a more specific study based on one of these themes, was selected for a couple reasons. First, by including all of these themes in the survey and in application to the case studies, attention is brought to the importance of a holistic approach to affordable housing, treating development as both an end for expanding the supply of affordable housing, and as a means for equitable development. Second, these themes are combined in order to see if there is some sort of hierarchy among them according to housing professionals. For example, does design outweigh access? This allows insight into general strategies and focuses of affordable housing 
Matijascic

development trends in Portland, therefore providing analysis not only of PCRI's affordable housing development strategies, but the development trends in the city.

The survey was created using Google Forms, due to its low cost and ease of use. The survey was distributed via email to 80 randomly selected specialists in the housing field, of whom 22 responded (27.5\% response rate). Originally, the survey was intended for distribution to the general public - anyone who lives in Portland - to emphasize that the focus was on public benefits. This was also the preferred audience because, as this report is conducted via a community-development informed lens, community involvement and public participation are seen as imperative to equitable, long-lasting plans and policies. However, for the sake of time and focus, the survey was sent to those working in the housing field only, since these are the actors who, due to the current way affordable housing is developed, have the most sway in the process.

In the survey, respondents were asked to rank each benefit according to how important they deemed it to be: Very important, important, unimportant, or very unimportant. There was no neutral answer because it was assumed that, since respondents work in the field, that they would understand the question and have a stance on each benefit. The survey is designed to be used anywhere. Surveys are a strategy to include voices of a variety of perspectives to better inform traditional approaches and methods. This survey is intended to be a template for researchers and developers in other cities in the US. For this reason, none of the language is Portland-specific. 
Matijascic

\section{$\underline{\text { Rationale and Results of Survey }}$}

In my emphasis of public benefits, I argue that affordable housing impacts - and therefore, has the potential to benefit - the entire city, not just residents or developers. This underscores the importance of comprehensive affordable housing policy. What are the strategies to promote public benefit, and which ones are more effective? To answer these questions, I created the survey to see which public benefits should be emphasized the most in plans and policies for affordable housing, according to professionals working in the field.

As the foundation of this study, the survey was designed carefully to minimize bias, to be meaningful to the respondents in order to encourage their participation, and to elicit accurate results. Each survey "question" is a specific public benefit or an opportunity to promote public benefit. Here, I provide the rationale for why I included each survey question, how it was applied in the assessment of case studies (see Appendix B), and how the survey respondents ranked the importance of the question (see Appendix A2). All questions received either a "very important" or "important" ranking by the majority of respondents. From this ranking, the question was assigned a point value ranging from 0 to 10 (see Appendix A3). This scale was chosen due to its ubiquity and ease of calculation.

The first question pertains to historical preservation. Preservation codes vary by city and neighborhood and are seen as both a valuable tool to preserve character, history, and culture, as well as a barrier to affordable development due to increased costs and lengthy permit processes. For this reason, it is valuable to see what developers in the community thought about this policy: $59 \%$ of respondents said this was "Very 
Matijascic

Important," and the remaining respondents said "important." This indicates that historical preservation is an excellent strategy to convey public benefit. In applying this to the case studies via site visits, rehabilitated properties were judged based on whether they appeared to preserve architectural features present in neighboring properties. New construction received points based on whether the unit's design respected the historical features of surrounding homes.

The second design question pertained to diversity in appearance of the housing. While this question appears to counter the previous question, it is still important: $91 \%$ of respondents ranked this characteristic as "important" or "very important". Here, the issue is not one of preservation but of avoiding monotonous design, which is often negatively associated with affordable housing. Respondents identified diversity as important, likely because diverse housing serves a wider variety of residents who need or want different home sizes, styles, and layouts.

The third question is whether an affordable development is cohesive with its context. Does the affordable development stands out as such? Or does it blend in with other homes in the neighborhood? A potential benefit of well-planned affordable housing is that it does not perpetuate negative stigmas associated with affordable housing, both for residents, as well as neighbors. Especially in the context of the four case studies scattered site affordable housing units located amongst mostly market rate housing - it is important that the unit "fit in" with the surrounding homes. While sixty percent of respondents ranked this benefit as "important", it is worth noting that efforts to make affordable housing units "fit in" - just like historical preservation and attention to 
Matijascic

diversity - can hinder affordable housing development through increased regulations and costs.

Some sources note the importance of certain design elements in building social capital and a sense of community, by facilitating interaction with neighbors and increasing safety (Design for Health, 2008). For this reason, question four addresses common design techniques that are perceived to serve such a purpose: the addition of a front porch, yard, or sidewalk access. If a property had either of these features, it received points. Fifty-nine percent of respondents ranked this characteristic as "important," with several responses of "very important" and "unimportant." This shows that this design feature is not perceived to be as beneficial as others. Perhaps this range of responses is because it is unknown whether these design features actually enhance connections between residents and neighbors, or if they are little more than well intentioned but superficial design features.

Questions five, six, and seven pertain to access and proximity to transportation, community spaces, and services. The Portland Plan, a strategic, multi-faceted plan adopted by the City in April 2012, includes access in its agenda for promoting housing affordability: "Neighborhood affordability (also) depends on access to essential services and lower-cost transportation options" (Portland Plan, p. 62). This is easily assessed for the case study properties using Google Maps to locate where services and amenities are located in relation to the case studies. Respondents overwhelmingly responded that this feature is "very important". When thinking about transportation access, a key component is the resident's choice of mode (bus, car, biking, walking, etc.). While this lends subjectivity to the question based on an individual's preference, it is important for a few 
Matijascic

reasons: first, choice empowers residents to live according to their own preference, rather than according to what is imposed upon them by a service provider or due to economic or social restrictions. Second, the City of Portland emphasizes active, non-car transportation (Portland Plan, p. 81). Active transportation is a public benefit because it decreases pollution as well as the financial burden imposed by car use and ownership. Lastly, while promoting active transportation is well-intentioned, it is hindered by the location of employment, schools, childcare, etc. in relation to one's residence. With the presence of multiple transportation options, a resident can choose the mode that is most time and cost effective for her/him.

Similarly, question six pertains to access to schools, parks, community centers, and community gardens. While these amenities may not be used daily - or at all - it is important (56\% of respondents say) that these resources are available, should a resident choose to take advantage of them. These features are considered central to building community and providing quality of life (Portland Plan).

Proximity to services such as a hospital, grocery store, or childcare facility is also "very important" (53\% of responses) in increasing quality of life as well as minimizing transportation time and costs. As with the previous two questions, proximity and access are characteristics that developers and housing professionals in Portland deem to be "very important" (55\% of respondents ranked the category of "access" as "very important").

Questions eight and nine address how the development process can be as effective as design and access features by providing public benefit through economic development. Question eight focuses on incentives to encourage developers to source labor and supplies locally, thus reinvesting development dollars back into the city (responses were 
Matijascic

quite varied, but "important" was the most common response). Question nine assesses the use of policies and incentives that encourage the hiring of women and minority contractors, which is "important" according to the majority of respondents. The Portland Housing Bureau (PHB) requires publicly funded projects to allocate at least $20 \%$ of construction costs to contracting with firms that are women-owned, minority-owned, or emerging small businesses (WMESB). If a developer is unable to meet these requirements, they must prove to the City that attempts were made to hire WMESB and were impossible to achieve. WMESB is part of the City's Business and Workforce Equity policy, and is Portland's application of HUD's Small Business Act (U.S. Department of Housing and Urban Development; Portland Housing Bureau, 2011).

Similarly, the Portland Housing Bureau (iteration of the HUD Section 3 program) requires that $10 \%$ of construction costs are devoted to contracting with Section 3 firms firms that employ $51 \%$ or more workers who are residents of the Portland Metro area, that live in Public or Indian Housing, and/or earn $80 \%$ or less of the MFI as calculated according to household size (City of Portland). This is another policy that encourages economic development during the development process.

Question ten pertains to fair wages, another important aspect of economic development through development, according to most respondents. There is a federal policy that encourages this: the Davis-Bacon Act. A progressive labor policy from the 1930's that is overseen by the U.S. Department of Labor, the Davis-Bacon Act requires that laborers hired to work on publicly funded contracts in excess of $\$ 2,000$ be paid the local minimum wage (U.S. Department of Labor). This policy interferes with the downward pressure of the market on wages, thereby increasing the cost of development. 
Matijascic

Some critics cite this as a hindrance to the production of affordable housing. This report, however, credits the Davis-Bacon Act with promoting an important, yet overlooked, public benefit that accompanies housing development: local economic development through fair wages. Of course, criticism abounds. It is difficult to enforce this law, since contractors report their hiring summaries voluntarily to the Department of Labor. Also, the minimum wage does not ensure a very high quality of life. Even though the DavisBacon Act could be revised to have greater impact, it sets a worthwhile standard that works toward public benefit through economic development.

All four case studies received full points for incorporating measures to encourage local economic development. This is because PCRI is required to adhere to the policies listed above. The assessments of the case studies show that these policies have a positive impact (see Appendix B2). The success of these policies in affecting long-term, truly equitable results is less certain. However, it is the first step in encouraging economic development, which is agreed among respondents of the survey to be very important to public benefit (see Appendix A2).

Respondents to the survey showed an overwhelming preference for nonprofit/CDC developers over private developers. Non-profit and CDC developers theoretically have an inherent interest in fair labor practices, consideration for their target demographic as well as the greater community, and long term affordability. They are better equipped to pursue these goals because they are less reliant on profit from their properties than private developers. Also, funding for non-profit/CDC developments largely comes from public funding sources which attach incentives and regulations that work to ensure equity and longer term affordability. Often, private developers have 
Matijascic

access to public funding and development incentives as well. Still, $83 \%$ of respondents agree that non-profits and CDC's are the preferred developer of affordable housing.

The final question introduces the public benefit of housing tenure, whether a household chooses to rent or own a home. Tenure is strongly correlated with age and income, as well as how long a household remains in their home (Harvard University, 2011). Respondents to the survey ranked tenure as an important consideration, due to its connection with neighborhood stability (see Appendix A2): owners tend to stay in their home longer than renters (Harvard University, 2011), therefore ownership is associated with greater stability, and therefore greater public benefit, than rental units.

One program that encourages homeownership, and therefore encourages longer unit tenure, is Down Payment Loan Assistance (DPAL) (City of Portland). DPAL provides a $0 \%$ interest loan for low-income families to pay the down payment and closing costs on a home. Unless the household sells the home within 10 years of the date of purchase, the loan is forgiven. DPAL is frequently used by PCRI when assisting clients in the home buying process. DPAL is an effective strategy on various levels: it compensates for lack of affordable housing options by providing access to market rate homes, it empowers low-income homebuyers by providing a greater array of options compared to designated affordable homes, and it generates wealth through equity. The relevance of DPAL to this report is the 10-year forgiveness policy, which incentivizes stability for residents and the neighborhood. Because of this policy and its use by PCRI, it is assumed that PCRI's homeownership units (Fessenden/Exeter and Russet/Rodney) have a use horizon for at least 10 years. From theoretical as well as practical studies (Center for Community Progress; Rohe and Stewart, 1996) we know that longer unit 
Matijascic

tenure tends to lead to a more stable neighborhood, and provides stability to the family that occupies it. For this reason, units for ownership receive more points than rental units. This is not to ignore residents who have rented long term. Still, if someone purchases their home, they will typically occupy the unit for a longer amount of time than a renter.

\section{$\underline{\text { Case Studies }}$}

The methodology of this report is designed to compare new construction to rehabilitated housing units. But without application, it is merely a hypothetical. In order to determine whether my methodology for assessing public benefits is helpful in reality, four properties were chosen as case studies. The controlled variables of these properties are the developer (PCRI), the location (North and Northeast Portland), and the time of development (completed in 2005 - 2012). I also wanted each case study to be a single family, detached home and to all have the same "use" - either all for rent or all for ownership. However, in order to conform to the aforementioned control variables, particularly keeping the developer the same, it was necessary to broaden the qualifications for selecting case studies. For this reason, the new construction case studies (4135 NE Rodney/47 Russet and 5105 N Fessenden) are duplexes (single family attached, two units) for ownership and the two rehabilitated units are single-family detached and for rent.

The difficulty I experienced in searching for comparable case studies shows that there is some degree of diversity of PCRI's affordable housing (a good sign, according to survey respondents, Appendix A2). Theoretically, this means that the developer, PCRI, 
Matijascic

is able to serve a wider range of incomes, household sizes, etc. It also alludes to the trends in affordable housing development among a specific developer and the market. Perhaps PCRI's focus on duplexes for their new construction projects reflects a wider trend, for example.

\section{$\underline{\text { Results }}$}

\section{Case Study Cost and Public Benefit Data}

\begin{tabular}{|l|l|l|l|l|}
\hline & 4135 NE Rodney & 5105 N & 1014 NE & 813 N Webster \\
& / 47 NE Russet & Fessenden & Emerson & \\
\hline Development & $\$ 388$ & (NEW) & (REHAB) & (REHAB) \\
foot per square & & $\$ 446$ & $\$ 76$ & $\$ 76$ \\
\hline Public Benefit & 74 & & & \\
Points & & 90 & 84 & 84 \\
\hline
\end{tabular}

When looking at the public benefits for the case studies, there are two strong trends. First, the public benefits of new construction and rehabilitation are comparable. This says that either strategy can convey public benefits to a fairly equal degree. Therefore, both strategies remain valuable. The second trend is that public benefits are very well incorporated in PCRI's developments; each case study comes close to reaching the maximum points (90). This confirms that PCRI meets nearly all of the points that housing professionals agree are important. The high level of public benefits provided by 
Matijascic

PCRI's developments also shows that policies that try to emphasize positive externalities of the development process are successful. Most of all, the data shows that a higher development cost does not necessarily result in greater public benefit.

The most striking difference between new construction and rehabilitation is not a discrepancy in public benefit, since they are actually on par with each other in this respect. It is the development cost that sets rehabilitation apart as the better affordable housing creation strategy. Even when the acquisition cost for a new construction development is the same as a rehabilitated project, the hard and soft costs for new construction are much higher. This finding echoes what Schaaf and Grigsby found in the literature explored above. While I deemed theirs an unbalanced analysis in their exclusion of social and public factors and benefits, it turns out that in the end, the question is about cost. Because public benefits were within the same range, the four case studies prove that both new construction and rehabilitation have the capacity to convey a high degree of public benefit - and not necessarily at a higher development cost.

\section{$\underline{\text { Conclusion }}$}

A primary theme of Portland's 40-year comprehensive city plan is Economic Prosperity and Affordability (Portland Plan, 2012). The document includes a "5-Year Action Plan" that draws attention to affordable housing: the need for an increase in supply and greater consideration of equity. There are several proposals for fulfilling this initiative, such as "address resource development, equity initiatives... and alignment with other community services for low and moderate income residents", "remove barriers to affordable housing" and "Increase the supply by building new affordable housing in high 
Matijascic

opportunity areas" (Portland Plan, 2012 p. 63). The fact that the City views affordable housing as a part of the Comprehensive Plan is promising. The results of this report certainly support this view; they also lend a suggestion in the pursuit of achieving the goals of the 5-Year Action Plan and the longer-term 40-year plan. Portland should focus policies and funding to promote rehabilitation in areas where a large stock of older homes exists, such as in North and Northeast Portland. The data also shows the capability of local CDC's of expanding the affordable housing stock in a way that maximizes public benefit, as reflected in the opinions of survey respondents ( $83 \%$ favored non-profit/CDC developers to private developers) and the high level of public benefit provided by PCRI's developments. In her essay about housing in Portland, Planning and Community Development scholar, Deborah Howe writes "Portland's future will be guided by a legacy of efforts to create a city that provides a quality living environment even for those of limited means" (Ozawa and Howe, 2004 p. 202). An emphasis on public benefit in the provision of housing contributes to the perception of Portland as a "livable" place, with the intent of making that perception a reality for everyone. 


\section{Works Cited}

Beauregard, R. A. (1986). The chaos and complexity of gentrification. In N. Smith \& P. Williams (Eds.), Gentrification of the City (pp. 35-55). Boston: Allen \& Unwin.

Center for Community Progress. Toolkit: Increasing Neighborhood Stability. Retrieved from www.communityprogress.net/increasing-neighborhood-stability-pages240.php

City of Portland. Bureau of Internal Business Services. Section 3 Program. Retrieved from www.portlandoregon.gov/bibs/58369

City of Portland. Portland Housing Bureau. Eligibility and Terms. Retrieved from www.portlandoregon.gov/phb/article/430181

City of Portland, City of Gresham, Multnomah County Consortium, (2012). Fair housing plan: 2011 analysis of impediments to fair housing choice and the strategies to address them

Coalition for a Livable Future: Equity Atlas Mapping Tool. African American Population Percent Change (2000-2010); 2000-2010 U.S. Census data. Retrieved from: https://clfuture.org/sites/clfuture.org/files/pdfs/Atlas_2_0/20002010_change_african_american.jpg

Design for Health. (2008). Planning Information Sheet: Building Social Capital with Comprehensive Planning and Ordinances. Version 1.2. www.designforhealth.net

Gibson, K. (2007). Bleeding Albina: A history of community disinvestment, 1940-2000. Transforming Anthropology, 15(1), 3-25.

Gramlich, E. (1990). A guide to benefit-cost analysis. (2nd ed.). Englewood Cliffs, NJ: Prentice Hall.

Cordell, K. (2013, March). Rental Market Madness. . Retrieved April 22, 2014, from http://www.portlandmonthlymag.com/real-estate/articles/rental-market-madness$\underline{\operatorname{march}-2013}$

Goetz, E. G. (1993). Shelter burden: local politics and progressive housing policy. (pp. 77-113). Philadelphia: Temple University Press.

Grigsby, W. G., \& Rosenburg, L. (1983). A closer look at modest rehabilitation. In D. Listokin (Ed.), Housing rehabilitation: Economic, social, and policy perspectives (pp. 93-99). New Brunswick, NJ: Center for Urban Policy Research. 
Matijascic

Harvard University Center for Housing Studies. (2013). The State of the Nation's Housing 2013. . Retrieved May 7, 2014, from http://www.jchs.harvard.edu/sites/jchs.harvard.edu/files/son2013.pdf

Jackson, K. (1985). Crabgrass frontier. (pp. 190-218). New York, NY: Oxford University Press.

Kolbe, P., Schenk, S., Burrell, L., \& Redding, S. (1998). Affordable housing in memphis: Revenue sources and cost-benefit analysis. The Foundation for Home Ownership. Memphis, TN,

Listokin, D. (1983). Housing rehabilitation: A strategy and literature come of age. In D. Listokin (Ed.), Housing rehabilitation: Economic, social, and policy perspectives (pp. 1-30). New Brunswick

Lycan, R., Pendleton, P., \& Weiss, J. Office of Planning and Development, Policy Development and Research Section City of Portland, Oregon. (1978). Residential mobility study for portland, or

Mallach, A. (2010). Bringing buildings back: From abandoned properties to community assets. (2nd ed., pp. 75-85, 302-344). Montclair, NJ: National Housing Institute.

Mission. (n.d.)..Retrieved May 21, 2014, from http://www.pcrihome.org/about/mission

Mundy (Ed.), (2009). State of black Oregon Retrieved from https://ir.library.oregonstate.edu/xmlui/bitstream/handle/1957/12301/UrbanLeagu e-StateofBlackOregon.pdf?sequence=1

Portland Plan. (2012). Adopted by the Portland City Council by Resolution 36918 on April 25, 2012. Retrieved from www.portlandonline.com/portlandplan/index.cfm?c=47906

Ozawa, C., \& Gibson, K. (2004). Urban Redevelopment in Portland: Making the City Livable for Everyone?. The Portland Edge: Challenges and Successes in Growing Communities (61-83). Washington: Island Press.

Ozawa, C., \& Howe, D. (2004). The Reality of Portland's Housing Market. The Portland Edge: Challenges and Successes in Growing Communities (184-205).

Washington: Island Press.

Pomeranz, W. (1983). How to tell if low-income housing rehabs make sense. In D. Listokin (Ed.), housing rehabilitation: economic, social, and policy perspectives (pp. 88-92). New Brunswick, NJ: Center for Urban Policy Research. 
Matijascic

Portland Housing Bureau. (2011). PHB Business Workforce and Equity Policy. Draft for PHAC Review/Discussion. Retrieved from http://efiles.portlandoregon.gov/webdrawer/rec/4176551/view/_DRAFT_\%20PH B\%20Business\%20Workforce\%20and\%20Equity.PDF

Rohe, W. M., Stewart, L. S. (1996). Homeownership and neighborhood stability. Housing Policy Debate, (Vol. 7, pp. 37-81).

Saegert, S. (2006). Building Civic Capacity in Urban Neighborhoods: an Empirically Grounded Anatomy. In Journal of Urban Affairs (Vol. 28, pp. 275-294).

Samuelson, P. A. (1954). The Pure theory of Public Expenditure. The Review of Economics and Statistics, 36, 387-389. Retrieved May 21, 2014, from https://instruct1.cit.cornell.edu/Courses/econ335/out/samuelson_pure.pdf

Schaaf, A. H. (1969). Economic feasibility analysis for urban renewal housing rehabilitation. Journal of the American Institute of Planners, 35(6), 399-404.

Stapleton, R. (2009). Tax increment financing: Comparing strategies in northwest states. Quarterly and Urban Development Journal, (3rd quarter), 34-49.

State of Washington, Department of Commerce. (2009). Affordable housing cost study

U.S. Census Bureau, (2013). Gross rent as percentage of household income, Portland, OR (2008-2012) and Selected monthly owner costs with a mortgage, Portland, OR (2008-2012) and selected monthly owner costs without a mortgage, Portland, OR (2008-2012). Retrieved from: http://factfinder2.census.gov/faces/tableservices/jsf/pages/productview.xhtml?fpt $=$ table

U.S. Department of Housing and Urban Development. Small and disadvantaged Business Utilization. Retrieved from http://portal.hud.gov/hudportal/HUD?src=/programdescription/smallbiz

U.S. Department of Labor. Wage and Hour Division. Davis-Bacon and Related Acts. Retrieved from www.dol.gov/whd/govcontracts/dbra.htm

Washington Area Housing Partnership, (2005). Toolkit for affordable housing development. Washington, D.C.:

White, W., Bole, R., \& Sheehan, B. (1997). Affordable housing cost study: an analysis of housing development costs in portland, oregon.

Wyly, E. K., \& Hammel, D. J. (2002). Neoliberal housing policy and the gentrification of the american urban system. 


\section{Appendix A: Public Benefits Survey}

\section{A1) Portland Affordable Housing Survey: Assessing Public Benefit}

Duration: 5 - 15 minutes

Structure: 18 short multiple-choice questions

The survey that you have received has been distributed to those working in the housing field in Portland, Oregon. The information from this survey will be used as part of a Cost Benefit Analysis to assess affordable housing creation in Portland, Oregon.

Below, you will find 18 potential public benefits of affordable housing. Public benefits are goods, which everyone and anyone can enjoy. An individual's utilization or enjoyment of such a good does not limit or detract from another individual's utilization or enjoyment of the good. Given this definition of "public benefit," please review the listed benefits. Rank each according to how important you deem them to be in regard to affordable housing development.

You may decline to answer any question that you do not wish to answer or that is unclear.

Response to this survey will allow for the assignment of numerical value to each public benefit, thereby providing a metric with which to compare the "benefits" with the "costs" of affordable housing development in Portland, Oregon. The resulting data and analysis will allow for affordable housing developers to better meet the demand for affordable housing in Portland by taking both monetary and non-monetary factors into account.

Thank you,

Sara Matijascic

Community Development Student

Portland State University

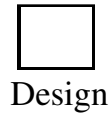

$$
\text { Very Important Important Unimportant } \quad \text { Very Unimportant }
$$

1.) Historical preservation of a building or neighborhood

2.) Diversity in appearance of housing (style, materials, etc.)

3.) Housing "fits in" with the

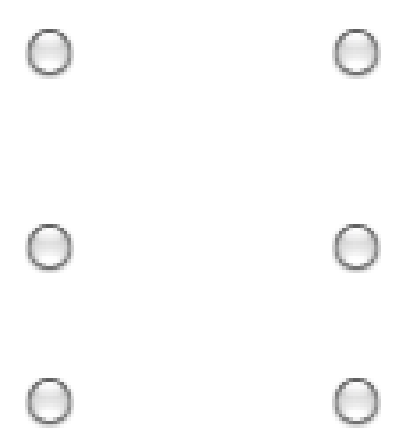


Matijascic

Very Important Important Unimportant $\quad$ Very Unimportant

neighborhood

4.) Unit design incorporates a front porch, yard, etc. to

facilitate

interaction with neighbors

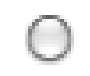

Access

$$
\text { Very Important Important Unimportant } \quad \text { Very Unimportant }
$$

5.) Access to transportation mode of choice within .25 miles (if driving, nearby parking; if public transit, proximity to stops and transit centers; etc.)

6.) Access to schools, a park/green space, community garden and community center within .5 miles

7.) Access to services within .5 miles (hospital/medical facility, grocery store, retail center, childcare, etc.)

Economic Development
Very Important
Important
Unimportant
Very Unimportant

8.) Increased employment and economic stimulus associated with the development process

9.) Emphasis on employment of workers from underrepresented groups 


\section{Matijascic}

Very Important Important Unimportant Unimportant

10.) Workers

involved in the

creation of

affordable housing

(construction,

carpentry, etc.) are

paid according to

minimum labor

rates

11.) Preservation

of existing

businesses and

increased

commercial

activity

Policy

$$
\text { Very Important Important Unimportant } \quad \text { Very Unimportant }
$$

12.) Policy to

ensure long-term

affordability (i.e.

extend "use

horizon")

Policy Part II13.) There should be greater allocation of public funds and increased incentives for to create affordable housing.

- $\square$ private developers

- $\square$ Community Development Corporations and other non-profit organizations

Community Development Part I14.) Which strategy should be emphasized:

- $\square$ Meeting the affordable housing needs of the greatest total number of people

- $\square$ Meeting the affordable housing needs of the people in greatest need (i.e. homeless), with a potentially lower number of total people in need of affordable housing assistance served

$$
\text { Very Important Important Unimportant Unimportant }
$$

15.) Affordable

housing meets the needs of a diverse array of people (i.e. families, seniors, disabled, culturally specific, mentally ill, etc.)

16.) Greater

options for residents regarding

housing location, size, style, etc. 


\section{Matijascic}

Very Important Important $\quad$ Unimportant $\quad$ Very Unimportant

17.) Increase the overall supply of affordable housing
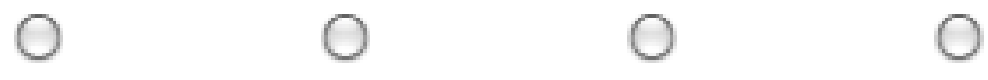

18.) Neighborhood

stabilization

(longer tenure of

resident in

unit/house)

Which sector do you work in?

Public Private Non-Profit/CDC




\title{
A2) Responses
}

\section{1.) Historical preservation of a building or neighborhood [Design]}

\author{
Very Important $1359 \%$ \\ Important $\quad 9 \quad 41 \%$ \\ Unimportant $\quad 0 \quad 0 \%$ \\ Very Unimportant $0 \quad 0 \%$
}

2.) Diversity in appearance of housing (style, materials, etc.) [Design]

$\begin{array}{lll}\text { Very Important } & 9 & 41 \% \\ \text { Important } & 11 & 50 \% \\ \text { Unimportant } & 2 & 9 \% \\ \text { Very Unimportant } 0 & 0 \%\end{array}$

3.) Housing "fits in" with the neighborhood [Design]

$\begin{array}{lll}\text { Very Important } & 7 & 32 \% \\ \text { Important } & 13 & 59 \% \\ \text { Unimportant } & 2 & 9 \% \\ \text { Very Unimportant } 0 & 0 \%\end{array}$

4.) Unit design incorporates a front porch, yard, etc. to facilitate interaction with neighbors [Design]
Very Important $\quad 836 \%$
Important $\quad 941 \%$
Unimportant $\quad 523 \%$
Very Unimportant $00 \%$

5.) Access to transportation mode of choice within .25 miles (if driving, nearby parking; if public transit, proximity to stops and transit centers; etc.) [Access] 
Matijascic

Very Important $1169 \%$

Important $\quad 531 \%$

Unimportant $\quad 0 \quad 0 \%$

Very Unimportant $0 \quad 0 \%$

6.) Access to schools, a park/green space, community garden and community center within .5 miles [Access]

Very Important $744 \%$

Important $\quad 956 \%$

Unimportant $\quad 00 \%$

Very Unimportant $00 \%$

7.) Access to services within .5 miles (hospital/medical facility, grocery store, retail center, childcare, etc.) [Access]

Very Important $\quad 853 \%$

Important $\quad 747 \%$

Unimportant $\quad 00 \%$

Very Unimportant $00 \%$

8.) Increased employment and economic stimulus associated with the development process [Economic Development]

Very Important $6 \quad 27 \%$

Important $\quad 1255 \%$

Unimportant $\quad 314 \%$

Very Unimportant $15 \%$

9.) Emphasis on employment of workers from underrepresented groups [Economic Development]
Very Important $941 \%$
Important $\quad 1045 \%$
Unimportant $\quad 3 \quad 14 \%$
Very Unimportant $0 \quad 0 \%$ 
10.) Workers involved in the creation of affordable housing (construction, carpentry, etc.) are paid according to minimum labor rates [Economic Development]

$\begin{array}{lll}\text { Very Important } & 9 & 43 \% \\ \text { Important } & 10 & 48 \% \\ \text { Unimportant } & 2 & 10 \% \\ \text { Very Unimportant } 0 & 0 \%\end{array}$

11.) Preservation of existing businesses and increased commercial activity [Economic Development]
Very Important $523 \%$
Important $\quad 1255 \%$
Unimportant $\quad 5 \quad 23 \%$
Very Unimportant $0 \quad 0 \%$

\title{
12.) Policy to ensure long-term affordability (i.e. extend "use horizon") [Policy]
}

\author{
Very Important $\quad 1673 \%$ \\ Important $\quad 5 \quad 23 \%$ \\ Unimportant $\quad 0 \quad 0 \%$ \\ Very Unimportant $1 \quad 5 \%$
}

\section{Policy Part II}

private developers

Community Development Corporations and other non-profit organizations 19 83\%

\section{Community Development Part I}

Meeting the affordable housing needs of the greatest total number of people $\quad 1053 \%$ Meeting the affordable housing needs of the people in greatest need (i.e. homeless), with a potentially lower number of total people in need of affordable $947 \%$ housing assistance served 
15.) Affordable housing meets the needs of a diverse array of people (i.e. families, seniors, disabled, culturally specific, mentally ill, etc.)

[Community Development]

Very Important $\quad 1568 \%$

Important $627 \%$

Unimportant $\quad 0 \quad 0 \%$

Very Unimportant $1 \quad 5 \%$

16.) Greater options for residents regarding housing location, size, style, etc. [Community Development]
Very Important $7 \quad 32 \%$
Important $\quad 1150 \%$
Unimportant $314 \%$
Very Unimportant $15 \%$

17.) Increase the overall supply of affordable housing [Community Development]

$\begin{array}{lll}\text { Very Important } & 17 & 77 \% \\ \text { Important } & 4 & 18 \% \\ \text { Unimportant } & 0 & 0 \% \\ \text { Very Unimportant } 1 & 5 \%\end{array}$

18.) Neighborhood stabilization (longer tenure of resident in unit/house) [Community Development]

\author{
Very Important $\quad 6 \quad 27 \%$ \\ Important $\quad 1464 \%$ \\ Unimportant $15 \%$ \\ Very Unimportant $15 \%$
}

Which sector do you work in?

Public $\quad 7 \quad 35 \%$ 
Matijascic

Private $\quad 15 \%$

Non-Profit/CDC 12 60\%

\section{A3) Public Benefit Point System}

Points are awarded based on the majority response for each question. If the majority is under $50 \%$, the points awarded are lower to capture the variety of responses.

All public benefits received either a "very important" or "important" majority.

If the majority of respondents ranked the public benefit as: 
Matijascic

Very Important - the benefit is worth 10 points if majority is greater than $50 \% ; 8$ points if less than $50 \%$

Important -6 points if greater than $50 \%, 4$ points if less than $50 \%$

Unimportant -0 points if greater than $50 \%, 2$ points if less than $50 \%$

Very Unimportant - 0 points

Appendix B: Case Studies

B1) Case Study Profiles

4135 NE Rodney/47 NE Russet - NEW 
Matijascic

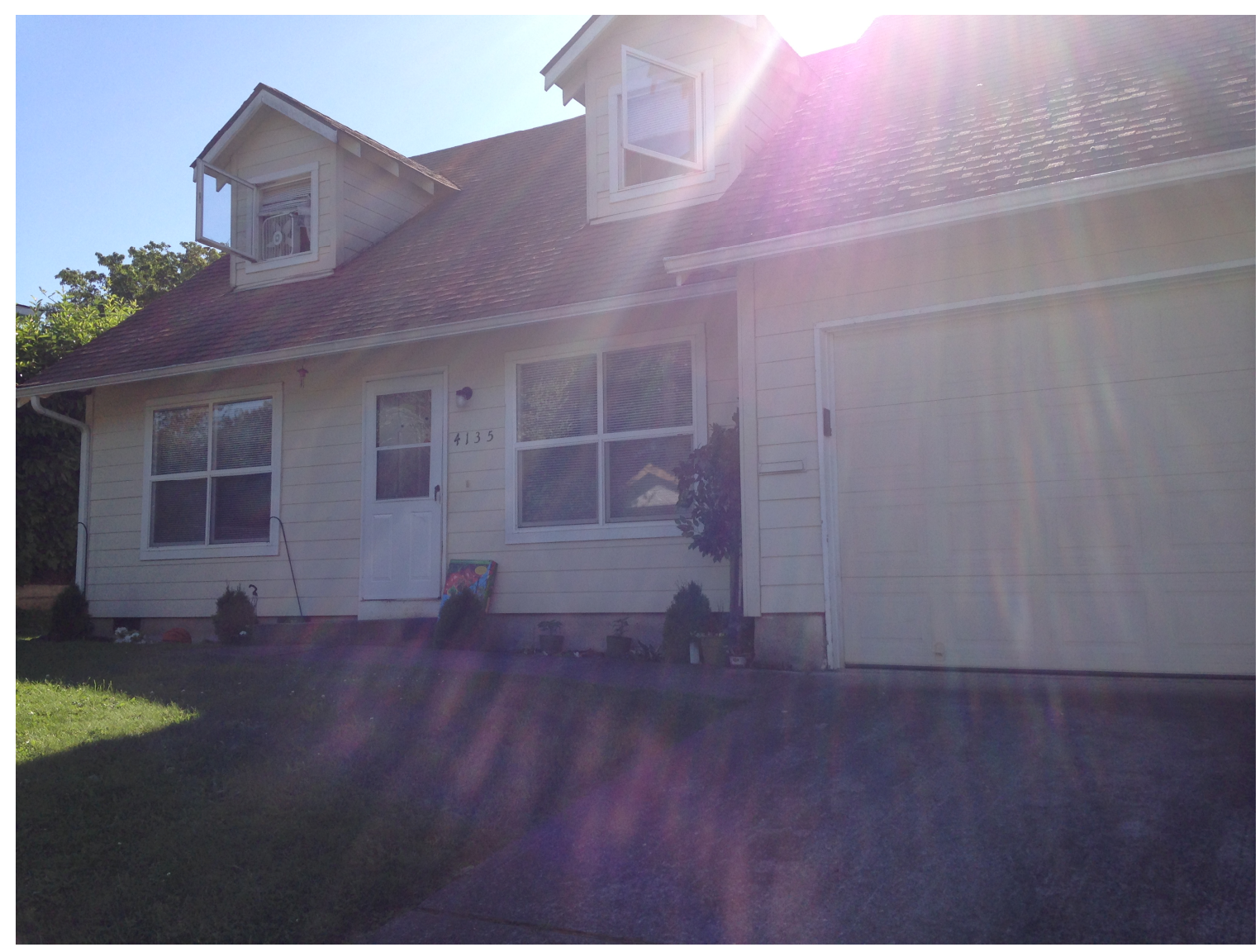

Year of Construction

2005

Use

\# units

\# bedrooms/unit

\# bathrooms/unit

Parking space

total SF

2,479

SF/unit

1,239

affordability

$60 \% \mathrm{MFI}$

5105 N Fessenden - NEW 


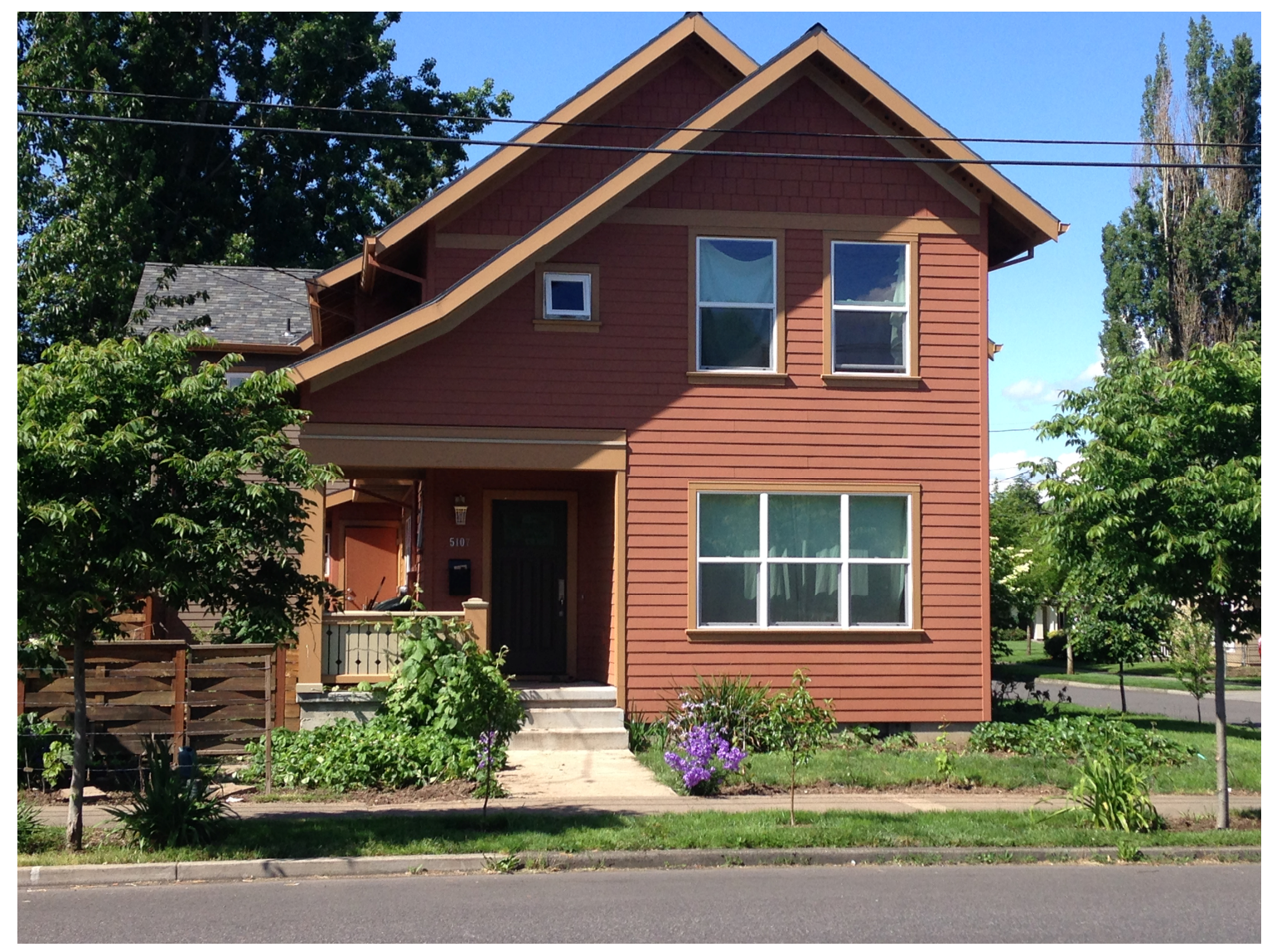

Year of Construction

Use

\# units

\# bedrooms/unit

\# bathrooms/unit

Parking space

total SF

SF/unit

affordability
2011

homeownership

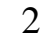

2

$270 \mathrm{sf}$

1,428

714

$55 \% \mathrm{MFI}$

1014 NE Emerson - REHAB 
Matijascic

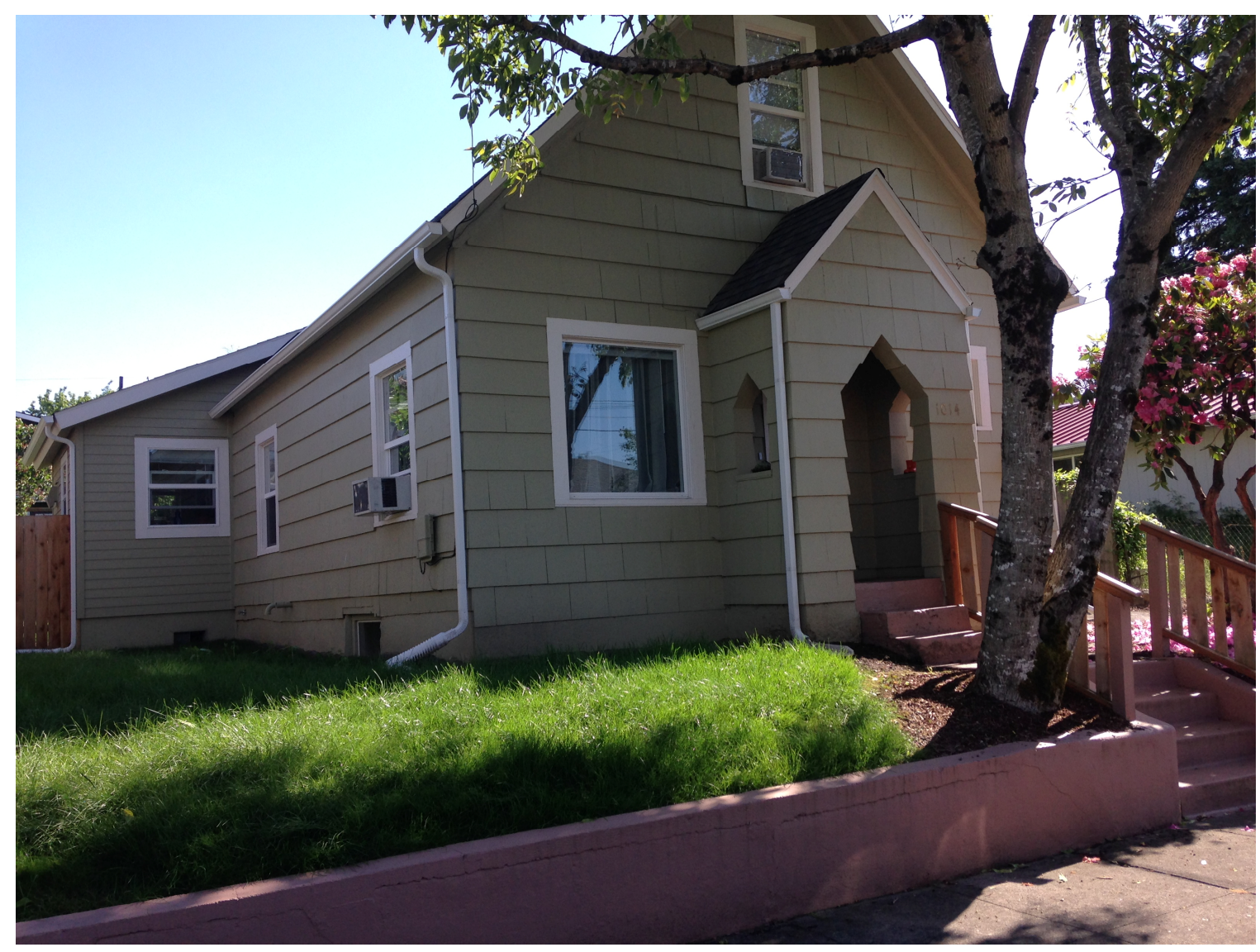

Year of Construction

2012

Use

rental

\# units

\# bedrooms/unit

\# bathrooms/unit

Parking space

total SF

1,256

SF/unit

1,256

affordability

$55 \% \mathrm{MFI}$

813 N Webster - REHAB 


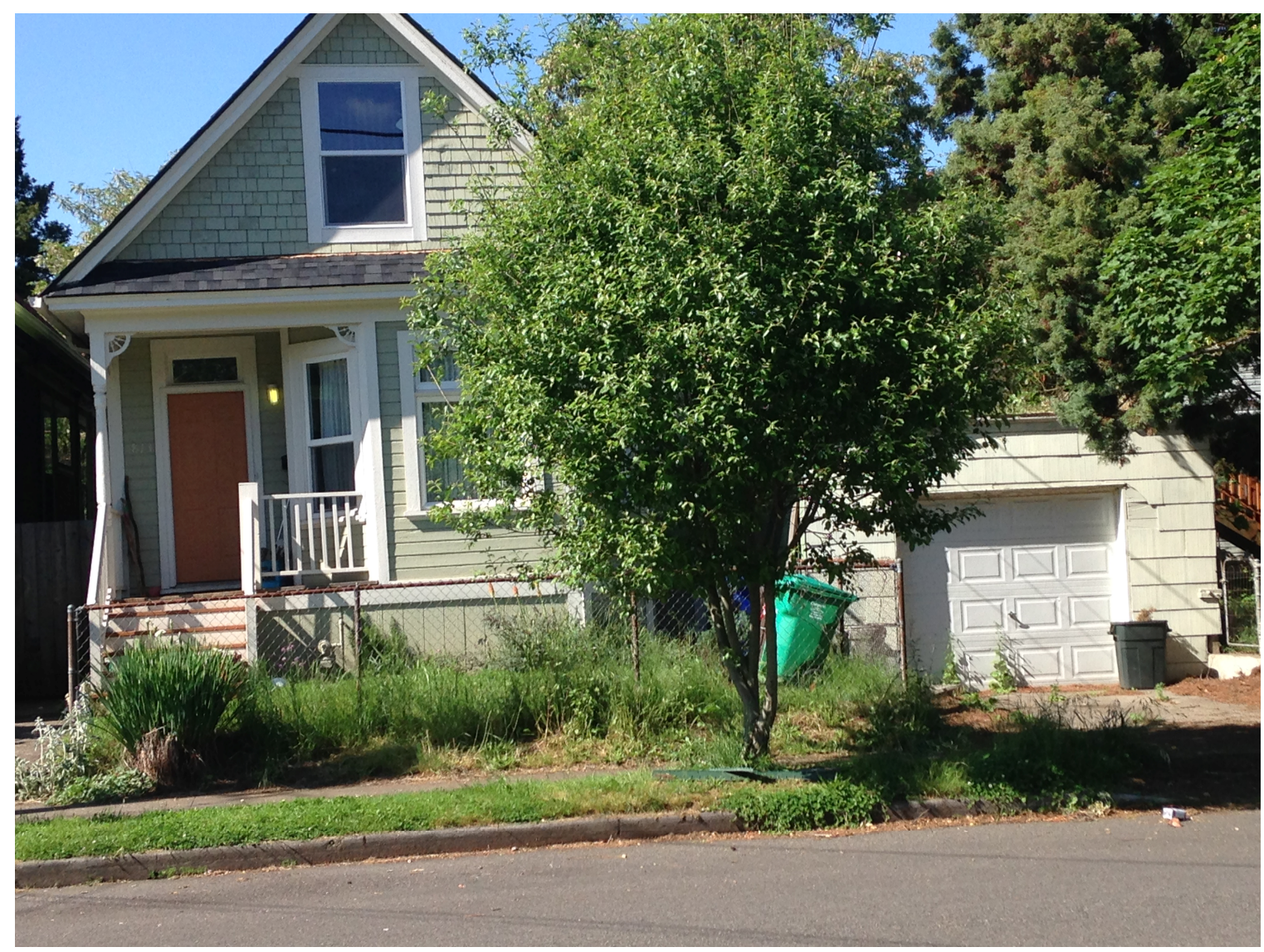

Year of Construction

2012

Use

rental

\# units

\# bedrooms/unit

\# bathrooms/unit

Parking space

total SF

1,149

SF/unit

1,149

affordability

$55 \%$ MFI

\section{B2) Benefits Assessment}

Public Benefits: Assessment of Case Studies 
1. Historical Preservation: REHAB - does the home appear to preserve historical building style based on date of construction and historical documents? NEW - does the style of the home appear to be sensitive of neighborhood historical preservation efforts?

2. Diversity in appearance of housing: do all/many of the homes share similar design features (house color, layout, size, landscaping/yard)?

3. "Fitting in": Does the home stick out from the rest as being "affordable"?

4. Design to facilitate interactions: does the property have a front yard, porch, and/or sidewalk access?

5. Access to Transportation mode of choice, .25 miles: does the property have two or more of the following within .25 miles:

-parking space
-transit stop
-bike lane
-sidewalk

6. Access to community amenities, .5 miles: Does the property have one or more of the following within .5 miles:

-school
-park
-community center
-community garden
-church

7. Access to services, .5 miles: does the unit have one or more of the following within .5 miles:

-hospital

-grocery store

-childcare facility

-retail center 
Matijascic

8. Economic stimulus from development: were labor and materials locally sourced and to what degree? (INTERVIEW/RESEARCH)

9. Employment of underrepresented groups: did the developer make an effort to employ women and people of color in the development of the property? Were they successful? (INTERVIEW/RESEARCH)

10. Fair wages for workers: were people employed for development and construction paid fairly? (INTERVIEW/RESEARCH)

11. Policy for long-term affordability: does this property have a "use horizon" and if so, how long must it remain affordable before it can become market rate?

12. Which sector should receive public support for development?: Is the developer of the property a CDC/non-profit or private?

13. Neighborhood Stabilization/tenure: is the property for rent or ownership?

\section{Appendix C: Cost Data}




\section{Matijascic}

\begin{tabular}{|c|c|c|c|c|c|}
\hline & & & Adjusted for Inflation (based on 2014 dollars) & & \\
\hline & & $\begin{array}{l}4135 \text { NE Rodney/47 NE Russet (Plex: } 2 \\
\text { Units) NEW }\end{array}$ & $5105 \mathrm{~N}$ Fessenden (Plex: 2 units) NEW & 1014 NE Emerson REHAB & 813 N Webster (I. URA) REHAB \\
\hline \multirow[t]{3}{*}{ Site Acquisition } & total & 0 & 83,200 & +2 & 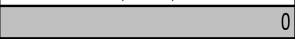 \\
\hline & per unit & 0 & 41,600 & 0 & 0 \\
\hline & per SF & 0 & 58 & 0 & 0 \\
\hline \multirow[t]{3}{*}{ Hard Costs } & total & 693,946 & $404,501.00$ & 87,489 & 68,588 \\
\hline & per unit & 346,973 & $202,250.00$ & 87,489 & 68,588 \\
\hline & per SF & 280 & 283.00 & 69 & 60 \\
\hline \multirow[t]{3}{*}{ Soft Costs } & total & 266,840 & 150,278 & 8,594 & 18,383 \\
\hline & per unit & 133,420 & 75,139 & 8,594 & 18,383 \\
\hline & per SF & 108 & 105 & 7 & 16 \\
\hline \multirow[t]{3}{*}{ Total Development Cost } & total & 960,786 & 637,980 & 96,083 & 86,969 \\
\hline & per unit & 480,393 & 318,990 & 96,083 & 86,969 \\
\hline & per SF & 388 & 446 & 76 & 76 \\
\hline
\end{tabular}

